\title{
Nitrogen Fertilization Impacts on Phosphorus Cycling in Grazed Grass-Legume Pasture
}

\author{
Sandra L. Dillard1, Charles Wesley Wood², Brenda H. Wood'2, Yucheng Feng', \\ Walter Frank Owsley ${ }^{1}$, Russell B. Muntifering ${ }^{1}$ \\ ${ }^{1}$ Department of Animal Sciences, Auburn University, Auburn, AL, USA \\ ${ }^{2}$ Department of Crop, Soil, and Environmental Sciences, Auburn University, Auburn, AL, USA \\ Email: Leanne.Dillard@ars.usda.gov
}

Received 14 August 2015; accepted 26 September 2015; published 29 September 2015

Copyright (C) 2015 by authors and Scientific Research Publishing Inc.

This work is licensed under the Creative Commons Attribution International License (CC BY).

http://creativecommons.org/licenses/by/4.0/

c) (i) Open Access

\begin{abstract}
The impact of different $N$ regimes on $P$ intake and excretion by grazing cattle and $P$ return to soil from feces in a P-enriched pasture was investigated. Six 0.28-ha plots were over seeded with triticale ( $\times$ Triticosecale rimpaui Wittm.) and crimson clover (Trifolium incarnatum) into tall fescue (Lolium arundinacea)/bermudagrass (Cynodon dactylon). Treatments included: $100 \%$ of $\mathrm{N}$ in split application, $50 \%$ of $\mathrm{N}$ in single application, and $0 \%$ of $\mathrm{N}$. In summer, plots were over seeded with cowpea (Vigna unguiculata) and fertilizer treatments were applied. Forage intake was estimated from fecal excretion and fecal degradation and nutrient return to soil at $0,28,56,84$, and 112 days after application were determined. Forage $P$ was not affected by season or treatment $(P>0.10)$; forage $P$ mass was greater in cool than warm season. Phosphorus intake and water-soluble $P$ output were not affected $(P>0.10)$ by season or treatment. Phosphorus output increased $(P=0.087)$ with increasing $N$ in cool season, but not warm season. Soil $P$ was greater $(P<0.0001)$ in warm than cool season. Feces remaining, $P$, and water-soluble $P$ in feces were not affected by $N$ treatment or season, but decreased $(P<0.10)$ with time. Sufficient $P$ was returned to soil from feces to support forage growth, even in the absence of $N$ fertilization. In a high-P pasture, $N$ did not affect intake and fecal returns of $P$ by cattle, foliar $P$ uptake, nor rate and extent of assimilation of $P$ into soil from feces.
\end{abstract}

\section{Keywords}

Feces, Decomposition, Phosphorus Mineralization 


\section{Introduction}

Animal manures have been used for millennia as a source of nutrients for crops of all types. With the advent of modern animal agriculture, manure-derived nutrients have become concentrated in production locales that cannot fully assimilate them. Nutrients such as $\mathrm{P}$ are potentially a major concern when considering quality of water runoff from beef cattle operations. When using manure from an animal feeding operation, manure is evenly spread across a pasture using a mechanical spreader or irrigation. However in grazed systems, urine and feces are not uniformly distributed throughout the pasture. A single beef-cow dung patch covers approximately 0.06 $\mathrm{m}^{2}$ [1]; and when calculated on an annual basis, the total surface area of a pasture that receives dung may only be $27 \%$ to $40 \%$ of the total area [2].

Cattle consuming forage-based diets require a daily minimum of $10 \mathrm{mg} \mathrm{P} / \mathrm{kg} \mathrm{BW}$ (body weight). The true absorption of dietary $\mathrm{P}$ is less than $68 \%$, resulting in at least one-third of total ingested $\mathrm{P}$ being directly excreted in feces from the animal [3]. The concentration of $\mathrm{P}$ in forages ranges from approximately $0.3 \%$ of dry matter (DM) in early growth to $0.15 \%$ in mature growth, and may be deficient for cattle subsisting on mature, dry forages. However, certain species (e.g., tall fescue, bermudagrass, and clovers) are able to bioaccumulate P [4] [5]. Furthermore, studies have shown that these $\mathrm{P}$ bioaccumulators exhibit both greater biomass production and greater foliar concentrations of $\mathrm{P}$ when adequate $\mathrm{N}$ fertilization is used [6] [7].

Only a small amount of endogenous P (approximately $0.27 \mathrm{~g} \mathrm{P} / \mathrm{d}$ ) is excreted in the urine by cattle [8] [9]. Therefore, feces is a sink for both biologically unavailable and available $\mathrm{P}$ in the diet, and the amount excreted is largely dependent on dietary intake [10]-[12]. Reference [13] reported cattle grazing pasture excreted 4.3 - 7.3 $\mathrm{mg}$ P/g fecal DM and at least $13.7 \mathrm{~kg}$ P were excreted annually per animal. Alternatively, fecal $\mathrm{N}$ loss is only approximately $0.6 \%$ of DM intake by the animal, with the majority of $\mathrm{N}$ being excreted through the urine [8]. The resulting N:P ratio of cattle fecal material is thus much narrower than that of the forage requirement and often leads to a buildup of $\mathrm{P}$ in the soil [14]. It has been estimated that soil $\mathrm{P}$ accumulation rates due to manure application in the USA and several European countries ranges from 8 to $40 \mathrm{~kg} \mathrm{Pha}^{-1} \cdot \mathrm{yr}^{-1}$ [15]. And while $\mathrm{N}$ and $\mathrm{P}$ in animal excreta are present in various forms, the majority of $\mathrm{N}$ is in excreta occuring in organic forms and $\mathrm{P}$ primarily in inorganic forms. Thus suggesting mineralization rates and nutrient availability in excreta depend on the nutrient and environmental conditions, such as soil moisture and temperature [15] [16].

While many studies [17]-[20] have determined the mineralization/return rate of P from cattle manure (feces, urine, and/or bedding material) to the soil, there is little research published that deals singularly with cattle feces, which can oftentimes be $\mathrm{N}$-limiting due to the small amount of endogenous $\mathrm{N}$ that is excreted in feces. Additionally, the return of $\mathrm{P}$ and $\mathrm{N}$ to the soil from fecal pats is affected by many environmental factors (e.g., air and soil temperature, soil moisture, etc.); thus, there is no universal standard by which to quantify mineralization, and location-specific estimations are required for individual physiographic and climatic regions [21]. The objective of the current study was to determine the effect of $\mathrm{N}$ fertilization of a year-round, grazed, grass/legume pasture on intake and fecal excretion of $\mathrm{P}$ by grazing cattle, and to characterize temporal patterns of $\mathrm{P}$ return to the soil ecosystem from fecal pats. We hypothesized that $\mathrm{N}$ fertilization would alter aboveground forage DM mass and foliar P concentration such that P intake and thus fecal excretion of $\mathrm{P}$ by cattle would be modified. Secondly, we hypothesized that pasture response to $\mathrm{N}$ fertilization would affect temporal patterns of disappearance of fecal pats such that feces from cattle grazing during the summer would disappear more rapidly and result in greater soil $\mathrm{N}$ and $\mathrm{P}$ concentrations than feces from cattle grazing during cool season.

\section{Materials and Methods}

\subsection{Research Site}

The experimental site comprised six instrumented runoff plots constructed in 2007 at the Stanley P. Wilson Beef Teaching Center of the Auburn University Department of Animal Sciences, Auburn, AL USA (32 53'34.43"N latitude, $85^{\circ} 30$ '3.32"W longitude, $187 \mathrm{~m}$ above MSL). Plots $(91.4 \times 30.5 \mathrm{~m}, 0.28 \mathrm{~h}$ each) ranged from 1 to $10 \%$ slope and consisted of a permanent common bermudagrass (Cynodon dactylon) and tall fescue (Lolium arundinaceum) sod on a Marvyn loamy sand (Fine-loamy, Kadinitic, thermic Typic Kanhapludult) and a Pacolet sandy loam (Fine, Kaolinitic, thermic Typic Kanhapludult) soil. Monthly mean and 20-yr average monthly mean temperatures at the research site between September 2010 and December 2012 are presented in Figure 1, and corresponding monthly total and 20-yr average monthly total precipitation during the same period are presented in Figure 2. 


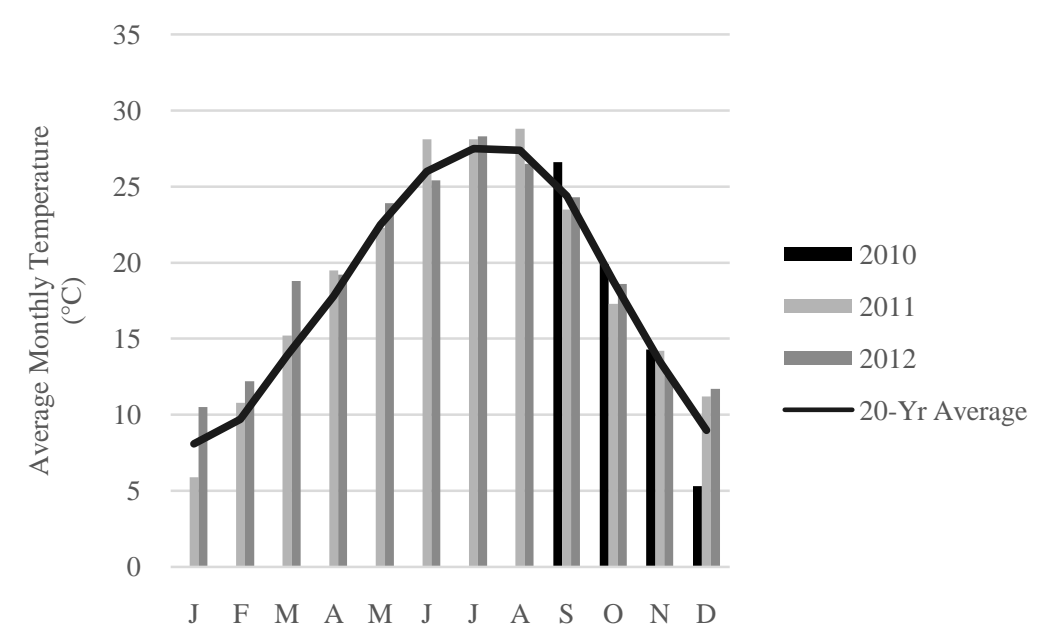

Figure 1. Monthly mean and 20-year average monthly mean temperatures between September 2010 and December 2012 at the Auburn University Stanley P. Wilson Beef Teaching Unit, Auburn, AL, USA.

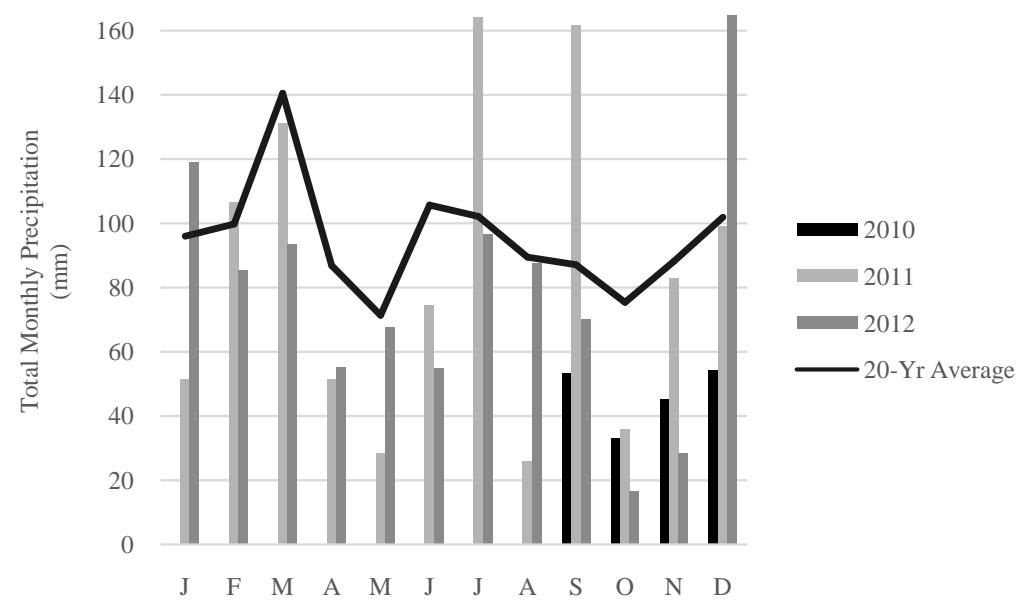

Figure 2. Monthly and 20-year average monthly total precipitation between September 2010 and December 2012 at the Auburn University Stanley P. Wilson Beef Teaching Unit, Auburn, AL, USA.

\subsection{Forage Establishment and Fertilization}

In October 2010 and 2011, plots were no-till drilled (Great Plains model 3P606NT with small seed box) with triticale ( $\times$ Triticosecale rimpaui Wittm. var. “Trical 2700”) at a seeding rate of $125.5 \mathrm{~kg} / \mathrm{ha}$ and with pre-inoculated crimson clover (Trifolium incarnatum var. "Dixie”) at a seeding rate of $33.6 \mathrm{~kg} / \mathrm{ha}$, and randomly assigned to 1 of 3 treatments (2 replicates/treatment): $0 \%$ of $\mathrm{N}(0 \mathrm{~N})$ recommendation for triticale, $50 \%$ of $\mathrm{N}(50 \mathrm{~N})$ recommendation for triticale $(50.4 \mathrm{~kg} \mathrm{~N} / \mathrm{ha})$ in a single application at planting, and $100 \%$ of $\mathrm{N}(100 \mathrm{~N})$ recommendation for triticale (100.8 $\mathrm{kg} \mathrm{N} / \mathrm{ha})$ in a split-application; the first at planting, and the second directly prior to turning out cattle into plots for grazing. Plots received $50.4 \mathrm{~kg} \mathrm{~N} / \mathrm{ha}$ in the form of ammonium sulfate-urea at the time of planting, and $100 \mathrm{~N}$ plots received an additional $50.4 \mathrm{~kg} \mathrm{~N} / \mathrm{ha}$ in February of each year. In May, after completion of the cool season (CS), plots were mowed to a 10-cm height using a mechanical mower to remove any standing forage. In June 2011 and 2012, plots were no-till drilled with cowpea (Vigna unguculata var. 'Iron Clay') at a seeding rate of $57 \mathrm{~kg} / \mathrm{ha}$. Cowpea seeds were inoculated prior to planting with N-Dure EL Type rhizobial inoculant (Intx Microbials, LLC, Kentland, IN) at a rate of $170 \mathrm{~g}$ inoculant per $23 \mathrm{~kg}$ seed. Plot assignments to fertilization treatments were the same as in the CS; for the warm season (WS), $\mathrm{N}$ fertilization rates 
were based on recommendations for bermudagrass. The $0 \mathrm{~N}$ treatment thus received $0 \mathrm{~kg} \mathrm{~N}$, the $50 \mathrm{~N}$ treatment received $56.0 \mathrm{~kg} \mathrm{~N} / \mathrm{ha}$ at time of planting, and the $100 \mathrm{~N}$ treatment received $112.0 \mathrm{~kg} \mathrm{~N} / \mathrm{ha}$ in a split-application at planting and prior to turning out cattle into plots for grazing. No pastures received irrigation or pesticide application during the experimental period.

\subsection{Cattle Management}

For both grazing seasons in 2011, six Red Angus $\times$ Beefmaster cattle (4 steers and 2 heifers, $328 \pm 60 \mathrm{~kg} \mathrm{BW}$ in CS; and 6 steers, $361 \pm 23 \mathrm{~kg}$ BW in WS) were randomly assigned to plots (1 animal/plot) and turned in to graze on February and July. Cattle were allowed to graze until forage samples from destructive harvests revealed that aboveground forage DM mass had decreased below $500 \mathrm{~kg}$ DM/ha (May and September, 2011). In 2012, six Angus cattle (4 steers and 2 heifers, $345 \pm 60 \mathrm{~kg}$ BW during CS; 6 steers, $312 \pm 31 \mathrm{~kg}$ BW during WS) were randomly assigned to plots ( 1 animal/plot) and turned in to graze in late-January and early August. Cattle were removed from plots when forage DM mass had decreased below $500 \mathrm{~kg} \mathrm{DM} / \mathrm{ha}$ (May and September). All animal activities were approved by the IACUC committee prior to the experiment.

\subsection{Chromium Pellet Fabrication}

In August 2010, chromic oxide $\left(\mathrm{Cr}_{2} \mathrm{O}_{3}\right) /$ corn pellets were fabricated for administration to grazing cattle in order to indirectly determine their daily fecal DM output by $\mathrm{Cr}$ dilution technique. A mixture of $\mathrm{Cr}_{2} \mathrm{O}_{3}$ and ground corn was blended in a ratio of $20.4 \mathrm{~kg}$ corn: $2.3 \mathrm{~kg} \mathrm{Cr}_{2} \mathrm{O}_{3}$ and fabricated into pellets containing $6.8 \% \mathrm{Cr}$ by weight. Pellets were formed using a laboratory-scale pellet mill (Model CL5, California Pellet Mill Co., San Francisco, CA) through a 4.76-mm dye. Pellets were dried for $24 \mathrm{~h}$ at room temperature and stored in an air-tight container until use.

\subsection{Phosphorus Intake and Fecal Excretion}

Daily forage DM intake was estimated by first determining fecal excretion of $\mathrm{Cr}$ from consumption of $\mathrm{Cr}_{2} \mathrm{O}_{3} /$ corn pellets. Cattle were individually fed $50 \mathrm{~g}$ ground corn twice daily for $10 \mathrm{~d}$ to familiarize them with handfeeding by personnel. Next, cattle were individually fed $10 \mathrm{~g} / \mathrm{d}$ of $\mathrm{Cr}_{2} \mathrm{O}_{3} /$ corn pellets for $7 \mathrm{~d}$ at $0800 \mathrm{~h}$. On day 7 , each animal was moved at $0800 \mathrm{~h}$ to a holding facility at the Stanley P. Wilson Beef Teaching Unit where feces were collected from a concrete floor immediately following excretion and placed into a bucket. All feces from 0800 to $1500 \mathrm{~h}$ from each animal were mixed, and a 500-g subsample (wet wt) was retained for Cr analysis. This experiment was conducted twice, midway and late in the grazing season, for each of CS and WS seasons in 2011 and 2012. Prior to analyses, fecal samples were dried at $60^{\circ} \mathrm{C}$ for $72 \mathrm{~h}$ and ground with a Wiley Mill (Thomas Scientific, Philadelphia, PA) to pass a 1-mm screen.

Three forage samples were obtained by destructive harvest in each plot within $7 \mathrm{~d}$ subsequent to fecal collections. Forage samples were clipped at $5 \mathrm{~cm}$ above ground surface from within a $0.25-\mathrm{m}^{2}$ quadrat, composited by paddock, dried at $60^{\circ} \mathrm{C}$ for $72 \mathrm{~h}$, and ground with a Wiley Mill (Thomas Scientific, Philadelphia, PA) to pass a 1-mm screen. Forage in vitro dry matter digestibility (IVDMD) was determined according to the [22] modification of the procedure developed by [23] using the Daisy II incubator system (Ankom Technology, Macedon, NY). Ruminal fluid was collected from a fistulated, dry Holstein cow at the Auburn University College of Veterinary Medicine. The cow was fed a corn silage-based diet containing cottonseed meal and Megalac supplement (Arm and Hammer Animal Nutrition, Ewing, NJ), and had free access to bermudagrass pasture and limited alfalfa (Medicago sativa) hay. Fluid was stored in pre-warmed thermos containers to maintain viability of the rumen microbial population and transported immediately to the Auburn University Ruminant Nutrition Laboratory where it was processed for the batch-culture IVDMD procedure.

Forage and fecal samples were analyzed for P and Cr using dry-ashing followed by ICAP spectroscopy [24]. Total fecal Cr was used to determine total fecal output using the equation

Daily fecal output $=\mathrm{Cr}$ intake $/ \mathrm{Cr}$ concentration in feces . Forage DM intake was calculated using the equation: Daily forage DM intake = Fecal DM output/\% Indigestibility [25]. Intake and fecal excretion of P were then calculated by multiplying forage and fecal concentrations of P by forage DM intake and fecal DM output, respectively. 


\subsection{Fecal Pat Degradation}

Twenty-four $1-\mathrm{m}^{2}$ plots were demarcated adjacent to the grazed pasture plots at the research site. These plots were mowed to a 4-cm height and sprayed with glyphosate prior to fecal-pat degradation experiments conducted over a 2-yr period. The study was arranged as a completely randomized design with two replications. Prior to feces collection in the CS and WS, three $20-\mathrm{cm}$ soil samples were taken from each 1- $\mathrm{m}^{2}$ plot and separated into 0 to 5,5 to 10, and 10 to $20 \mathrm{~cm}$ depth strata. In the CS and WS of 2011 (April 21 and September 14, respectively) and 2012 (April 11 and September 12, respectively), feces were collected directly from each animal in each pasture. Each animal was brought to the Stanley P. Wilson Beef Teaching Unit holding facility at $0800 \mathrm{~h}$ where feces were collected from a concrete floor immediately following excretion and placed into a bucket. All feces from 0800 to $1500 \mathrm{~h}$ from each animal were composited and allocated to 0-, 28-, 56-, 84-, and 112-d after application (DAA) treatments, and a 500-g fecal sample (wet wt) was prepared for each DAA treatment. Zero-DAA fecal samples were taken directly to the laboratory and dried at $60^{\circ} \mathrm{C}$ for $72 \mathrm{~h}$. All remaining DAAtreatment fecal aliquots were transported from the holding facility to the experimental plots and randomly placed in the center of the $1-\mathrm{m}^{2}$ plot. Feces were applied so that a $20-\mathrm{cm}$ diameter fecal pat was constructed in the center of each plot, which ensured that no cross-contamination of nutrients occurred between plots during the trial.

On the assigned treatment DAA, remaining fecal material that had not decomposed was recovered by removing any visible fecal matter remaining on soil from each plot, and subsequently weighed. Three additional soil samples were taken from directly beneath fecal pats and separated into 0 to 5, 5 to 10 , and 10 to $20 \mathrm{~cm}$ depth strata. Feces and soil were dried at $60^{\circ} \mathrm{C}$ for $72 \mathrm{~h}$. Fecal samples were ground with a Wiley Mill (Thomas Scientific, Philadelphia, PA) to pass a 1-mm screen, and all soil samples were sieved to pass a 2-mm screen.

Soil and fecal concentrations of $\mathrm{N}$ were determined via dry combustion using a LECO TruSpec CN Analyzer (LECO Corp, St Joseph, MI). Soil samples were extracted using dilute $\mathrm{HCl}$ and $\mathrm{HNO}_{3}$ (Mehlich 3), and analyzed by ICAP spectroscopy to determine P (Spectro Ciros CCD, Kleve, Germany) [24]. Concentrations of P in fecal samples were analyzed by dry-ashing followed by ICAP spectroscopy [24]. Fecal samples were also analyzed for water-extractable P using the [26] method. Mean nutrient composition of feces is reported in Table 1. Total remaining nutrients in feces were calculated by the equation Nutrient remaining $=N \times D / 1000$, where $N$ is the concentration of the nutrient and $\mathrm{D}$ is the dry weight of the feces on a given DAA.

\subsection{Statistical Analysis}

Data were analyzed as a completely randomized design using PROC MIXED of Statistical Analysis Software (SAS, Carey, NC). Fecal nutrient and P utilization data were analyzed using N-fertilization treatment, season and their interaction as main effects. The soil nutrient model included $\mathrm{N}$-fertilization treatment, season, soil depth, DAA and their interactions as main effects. Orthogonal contrasts were used to compare the $0 \mathrm{~N}$ treatment

Table 1. Nutrient composition of feces (dry wt. basis) from cattle grazing pastures receiving different $\mathrm{N}$-fertilization and used in fecal degradation study.

\begin{tabular}{|c|c|c|c|c|}
\hline \multirow{2}{*}{ Item } & \multirow{2}{*}{ Season $^{\mathrm{b}}$} & \multicolumn{3}{|c|}{$\mathrm{N}_{\text {Treatment }}{ }^{\mathrm{a}}$} \\
\hline & & $0 \mathrm{~N}$ & $50 \mathrm{~N}$ & $100 \mathrm{~N}$ \\
\hline \multirow[t]{2}{*}{ DM (\%) } & CS & 14.0 & 15.2 & 13.2 \\
\hline & WS & 13.8 & 13.5 & 12.1 \\
\hline \multirow[t]{2}{*}{ P (\%) } & CS & 4.2 & 5.2 & 4.7 \\
\hline & WS & 6.5 & 7.1 & 5.8 \\
\hline \multirow[t]{2}{*}{ Water-soluble P (\%) } & CS & 2.2 & 1.5 & 1.4 \\
\hline & WS & 2.4 & 1.5 & 1.0 \\
\hline \multirow[t]{2}{*}{ N (\%) } & CS & 2.2 & 2.4 & 2.5 \\
\hline & WS & 2.5 & 2.6 & 2.1 \\
\hline
\end{tabular}

${ }^{\mathrm{a}} 0 \mathrm{~N}=0 \% \mathrm{~N}$ fertilization, $50 \mathrm{~N}=50 \% \mathrm{~N}$ fertilization, $100 \mathrm{~N}=100 \% \mathrm{~N}$ fertilization based on $\mathrm{N}$ requirement of grass species. ${ }^{\mathrm{b}} \mathrm{CS}=$ cool season and $\mathrm{WS}=$ warm season. 
with $50 \mathrm{~N}$ and $100 \mathrm{~N}$ treatments, and $50 \mathrm{~N}$ and $100 \mathrm{~N}$ treatments. In recognition of the low statistical power characteristic of field studies that employ limited numbers of replicates, $\alpha$ was set to equal 0.10 [27]. Due to lack of a significant year effect, all data presented are pooled across both years.

\section{Results and Discussion}

\subsection{Phosphorus Intake and Fecal Excretion}

Phosphorus concentration in forage available to cattle during the experimental period (Table 2) was not different $(P>0.10)$ between seasons or among treatments. However, forage DM mass was greater $(P=0.008)$ for CS forage than WS forage, and P mass was greater $(P=0.023)$ for CS forage than WS forage. Neither DM mass nor forage $\mathrm{P}$ mass were different $(P>0.10)$ among $\mathrm{N}$-fertilization treatments. Foliar $\mathrm{P}$ concentration and therefore, forage $\mathrm{P}$ mass were affected by soil $\mathrm{P}$ status, $\mathrm{P}$ fertilization, stage of forage maturity, forage management practices, $\mathrm{P}$ apportionment among individual plant species, and meteorological conditions [28].

Phosphorus intake by cattle (Table 3$)$ was not different $(P>0.10)$ between grazing seasons or among

Table 2. Forage DM mass, foliar $\mathrm{P}$ concentration, and forage $\mathrm{P}$ mass of pastures receiving different N-fertilization treatments.

\begin{tabular}{|c|c|c|c|c|c|c|}
\hline \multirow{2}{*}{ Item } & \multirow{2}{*}{ Season $^{\mathrm{b}}$} & \multicolumn{4}{|c|}{ N Treatment ${ }^{\mathrm{a}}$} & \multirow{2}{*}{$\mathrm{SEM}^{\mathrm{c}}$} \\
\hline & & $0 \mathrm{~N}$ & $50 \mathrm{~N}$ & $100 \mathrm{~N}$ & Mean & \\
\hline DM mass & CS & 3360 & 3580 & 3945 & $3628^{\mathrm{d}}$ & \\
\hline \multirow[t]{2}{*}{ (kg/ha) } & WS & 2722 & 2492 & 2622 & $2612^{\mathrm{e}}$ & \\
\hline & Mean & 3041 & 3036 & 3284 & 3120 & 258 \\
\hline P concentration & CS & 0.28 & 0.24 & 0.22 & 0.25 & \\
\hline \multirow[t]{2}{*}{ (\%) } & WS & 0.23 & 0.28 & 0.22 & 0.24 & \\
\hline & Mean & 0.25 & 0.26 & 0.22 & 0.25 & 0.01 \\
\hline Forage $\mathrm{P}$ mass & CS & 3.4 & 3.6 & 3.9 & $3.6^{\mathrm{f}}$ & \\
\hline \multirow[t]{2}{*}{ (kg/ha) } & WS & 2.7 & 2.5 & 2.6 & $2.6^{\mathrm{g}}$ & \\
\hline & Mean & 3.1 & 3.1 & 3.3 & 3.1 & 0.3 \\
\hline
\end{tabular}

${ }^{\mathrm{a}} 0 \mathrm{~N}=0 \% \mathrm{~N}$ fertilization, $50 \mathrm{~N}=50 \% \mathrm{~N}$ fertilization, $100 \mathrm{~N}=100 \% \mathrm{~N}$ fertilization based on $\mathrm{N}$ requirement of grass species. ${ }^{\mathrm{b}} \mathrm{CS}=$ cool season and WS = warm season. ${ }^{\mathrm{c}} \mathrm{n}=6$. $^{\mathrm{d}, \mathrm{e}}$ Within a column, means without a common superscript $\operatorname{differ}(P<0.10){ }^{\mathrm{f}, \mathrm{g}}$ Within a column, means without a common superscript differ $(P<0.05)$.

Table 3. Phosphorus intake, fecal P output, and fecal water-soluble P output by cattle grazing pastures receiving different $\mathrm{N}$-fertilization treatments.

\begin{tabular}{|c|c|c|c|c|c|c|c|c|c|}
\hline \multirow{3}{*}{ Item } & \multirow{3}{*}{ Season $^{\mathrm{b}}$} & \multirow{2}{*}{\multicolumn{4}{|c|}{ N Treatment ${ }^{\mathrm{a}}$}} & \multicolumn{4}{|c|}{ Contrasts } \\
\hline & & & & & & \multicolumn{2}{|c|}{$0 \mathrm{~N}$ vs. $[50 \mathrm{~N}+100 \mathrm{~N}]$} & \multicolumn{2}{|c|}{$50 \mathrm{~N}$ vs. $100 \mathrm{~N}$} \\
\hline & & $0 \mathrm{~N}$ & $50 \mathrm{~N}$ & $100 \mathrm{~N}$ & Mean & $P$ value & SEM $^{\mathrm{c}}$ & $P$ value & $\mathrm{SEM}^{\mathrm{c}}$ \\
\hline \multirow{3}{*}{$\begin{array}{l}\text { P intake } \\
(\mathrm{g} / \mathrm{d})\end{array}$} & CS & 11.2 & 25.1 & 33.4 & 23.2 & 0.229 & 14.7 & 0.578 & 14.7 \\
\hline & WS & 14.2 & 14.6 & 13.7 & 14.2 & 0.998 & 12.3 & 0.951 & 14.2 \\
\hline & Mean & 12.7 & 19.8 & 23.5 & 18.7 & & & & \\
\hline \multirow{3}{*}{$\begin{array}{l}\text { P output } \\
\text { (g/d) }\end{array}$} & CS & 7.1 & 12.1 & 29.5 & 16.2 & 0.154 & 9.4 & 0.093 & 10.1 \\
\hline & WS & 16.9 & 17.0 & 15.8 & 16.6 & 0.954 & 8.5 & 0.905 & 10.1 \\
\hline & Mean & 12.0 & 14.6 & 22.7 & 16.4 & & & & \\
\hline Water- & CS & 1.8 & 0.6 & 1.5 & 1.3 & 0.717 & 2.1 & 0.718 & 2.4 \\
\hline soluble P & WS & 2.6 & 4.4 & 1.4 & 2.8 & 0.876 & 2.1 & 0.205 & 2.4 \\
\hline $\begin{array}{l}\text { output } \\
\text { (g/d) }\end{array}$ & Mean & 2.2 & 2.5 & 1.4 & 2.1 & & & & \\
\hline
\end{tabular}

${ }^{\mathrm{a}} 0 \mathrm{~N}=0 \% \mathrm{~N}$ fertilization, $50 \mathrm{~N}=50 \% \mathrm{~N}$ fertilization, $100 \mathrm{~N}=100 \% \mathrm{~N}$ fertilization based on $\mathrm{N}$ requirement of grass species. ${ }^{\mathrm{b}} \mathrm{CS}=$ cool season and $\mathrm{WS}=$ warm season. ${ }^{c} n=6$. 
$\mathrm{N}$-fertilization treatments. A treatment $\times$ season interaction $(P=0.087)$ was observed such that fecal $\mathrm{P}$ output in CS was greater $(P<0.10)$ for $100 \mathrm{~N}$ than $50 \mathrm{~N}$, but was not different in WS. According to [3], medium-frame growing beef cattle require approximately 10 to $12 \mathrm{~g} \mathrm{P} / \mathrm{d}$. In the current study, cattle ingested at least $11.2 \mathrm{~g} \mathrm{P} / \mathrm{d}$, which is within the recommended intake. Reference [28] has stated that cattle grazing forage typically only become $\mathrm{P}$ deficient when soil is deficient in $\mathrm{P}$ because foliar $\mathrm{P}$ concentration and animal performance are both positively correlated with soil P concentration. Several studies [10]-[12] have reported that fecal P excretion is directly related to $\mathrm{P}$ intake, and that a positive correlation exists between increased $\mathrm{P}$ in the diet and increased fecal P excretion. Reference [12] has suggested that dietary P intake could be estimated from fecal P excretion. Reference [14] observed that $\mathrm{P}$ uptake from high-P soils increased with increasing $\mathrm{N}$-fertilization rate in CS grasses up to a N application rate of $168 \mathrm{~kg} \cdot \mathrm{ha}^{-1} \cdot \mathrm{yr}^{-1}$; in WS, N-fertilization rate did not have as much of an impact, but P uptake increased from $14.2 \mathrm{~kg} / \mathrm{ha}$ to $18.6 \mathrm{~kg} / \mathrm{ha}$. Increased foliar P uptake could explain increased P intake and fecal P excretion observed in the CS of the current study. Fecal concentration of water-soluble P was not different between seasons or among treatments $(P>0.10)$, but the mean concentration $(0.2 \mathrm{~g} / \mathrm{kg})$ is similar to values $(\sim 0.7 \mathrm{~g} / \mathrm{kg})$ reported by [19] for fresh beef cattle feces.

\subsection{Fecal Dry Matter Degradation}

Percentage of fecal-pat DM remaining (Figure 3) was not different among N-fertilization treatments or between

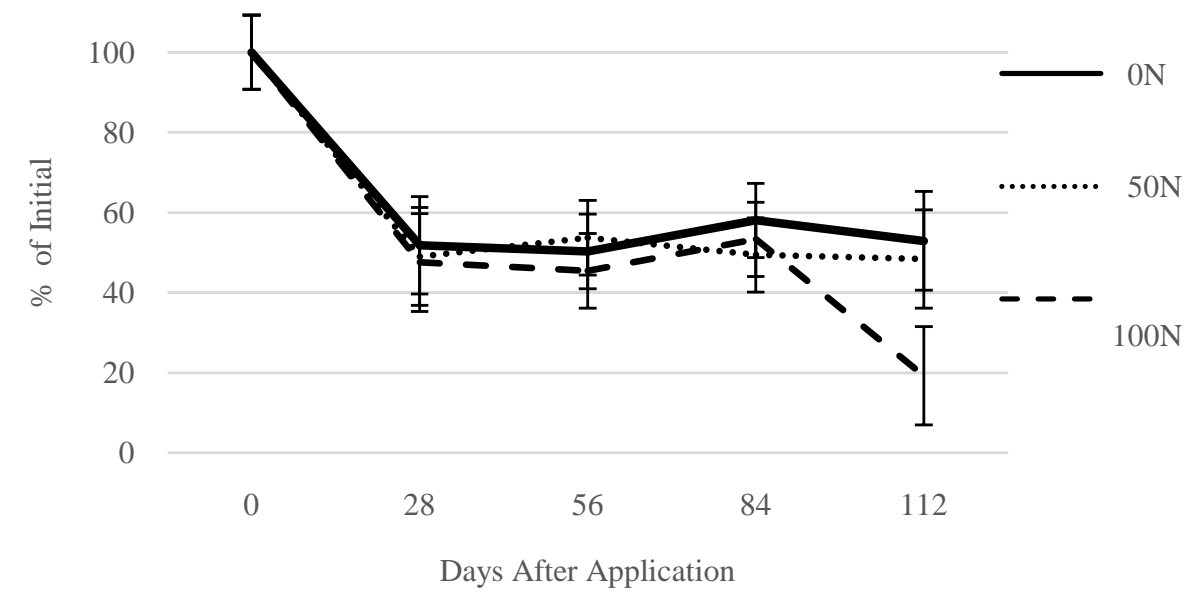

(a)

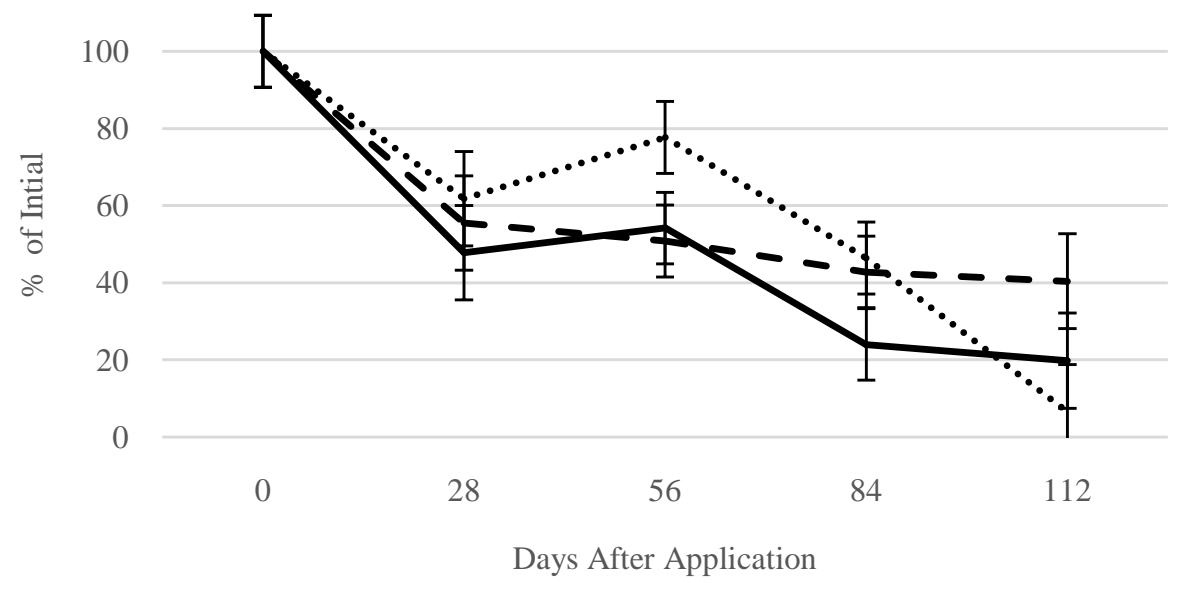

(b)

Figure 3. Dry matter mass remaining (\% of initial) in fecal pats from cattle grazing pastures receiving $0(0 \mathrm{~N}), 50(50 \mathrm{~N})$, or $100 \%(100 \mathrm{~N}) \mathrm{N}$-fertilization treatments during the cool season (a) and warm season (b). Vertical bars represent standard error of the mean $(n=6)$. 
seasons. The percentage remaining at 28 DAA was greater $(P<0.037)$ than at $112 \mathrm{DAA}$, but was not different $(P>0.10)$ from 56 and 84 DAA. Percentage remaining at 112 DAA was less $(P<0.037)$ than at 0,28 and 56 DAA. Reference [20] reported that cattle manure pats had only been reduced by $15 \%$ after 15 weeks. Reference [20] reported that cattle manure applied in the winter had decayed by $25 \%$ in $140 \mathrm{~d}$, and in the summer by $46 \%$ in $140 \mathrm{~d}$. Other studies have reported that cattle manure decomposed to approximately 50\% of initial mass in 80 $\mathrm{d}$ [29]. In the current study, fecal pats were reduced by an average of $68.8 \%$ in $112 \mathrm{~d}$, which is greater than values reported by [20], but similar to both [21] [29].

Percentage of $P$ remaining in fecal pats (Figure 4) was not different $(P>0.10)$ among treatments or between seasons. Zero DAA had a greater $(P<0.002)$ percentage remaining than all other DAAs. Additionally, 28 DAA had greater $(P<0.0001)$ remaining $P$ than 84 and 112 DAA. However, 56, 84 and 112 DAA were not different $(P>0.10)$. Within the WS, percentage of $P$ remaining at 112 DAA was greater $(P=0.010)$ in $100 \mathrm{~N}$ than $50 \mathrm{~N}$, and greater $(P=0.018)$ in $[50 \mathrm{~N}+100 \mathrm{~N}]$ than $0 \mathrm{~N}]$. Percentage of water-soluble P remaining (Figure 5) was not different $(P>0.10)$ among treatments or between seasons. Additionally, there was no difference among DAA $(P>0.10)$. Within WS, the percentage of water-soluble $P$ remaining at 112 DAA was greater $(P=0.084)$ in $100 \mathrm{~N}$ than $50 \mathrm{~N}$, and $100 \mathrm{~N}$ was greater $(P=0.054)$ than $50 \mathrm{~N}$ in the CS at $28 \mathrm{DAA}$. Whereas mass of total $\mathrm{P}$ and water-soluble $\mathrm{P}$ remaining in fecal pats were not different among DAA, values decreased over time. Reference [17] reported that $P$ disappearance from fecal pats mirrored disappearance of organic matter of soil-applied manure, consistent with the current study in which values for percentage of DM remaining and percentage of $P$ remaining were similar at every DAA. Reference [20] reported that after $15 \mathrm{wk}, 80 \%$ of P remained within manure

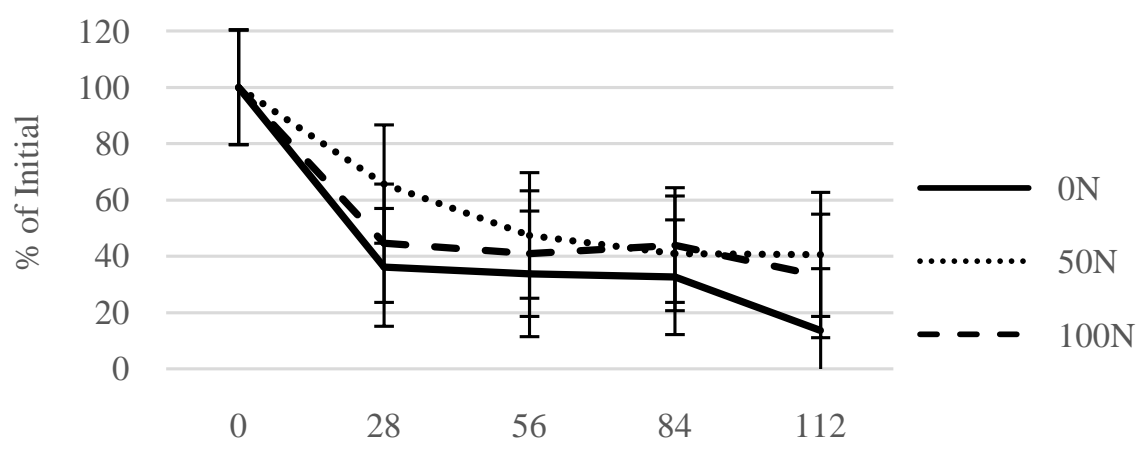

Days After Application

(a)

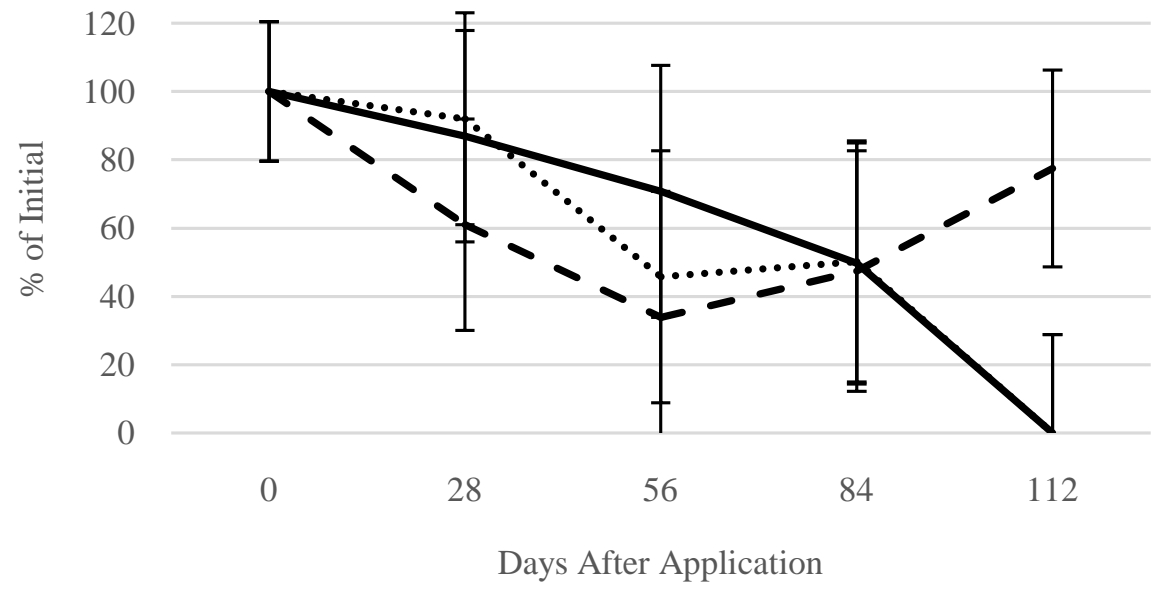

(b)

Figure 4. Phosphorus remaining (\% of initial) in fecal pats from cattle grazing pastures receiving $0(0 \mathrm{~N}), 50(50 \mathrm{~N})$, or $100 \%(100 \mathrm{~N}) \mathrm{N}$-fertilization treatments during the cool season (a) and warm season (b). Vertical bars represent standard error of the mean $(n=6)$. 


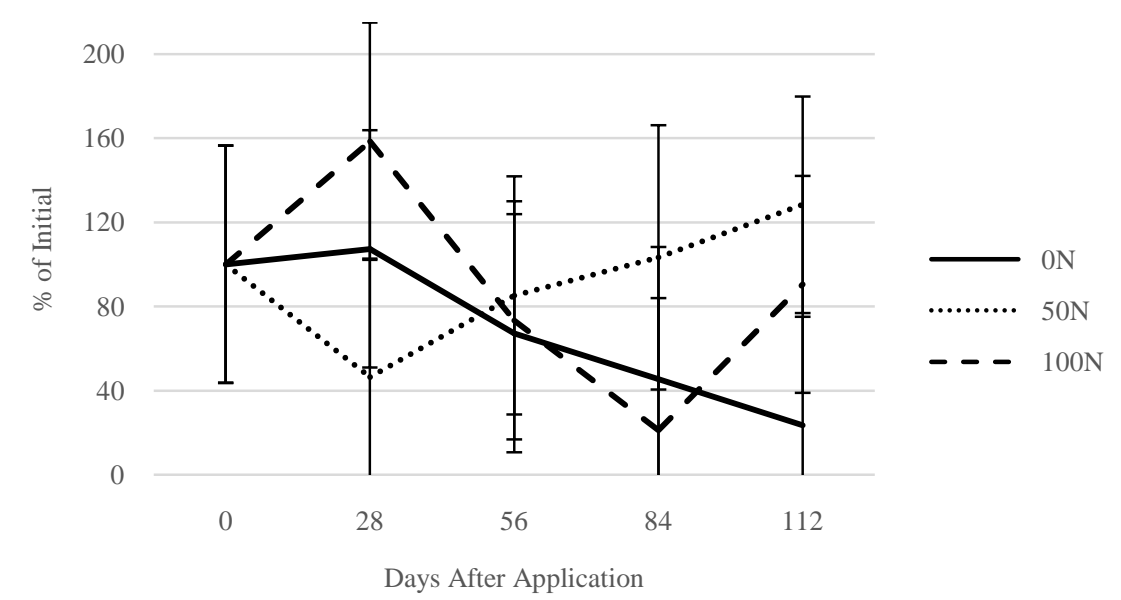

(a)

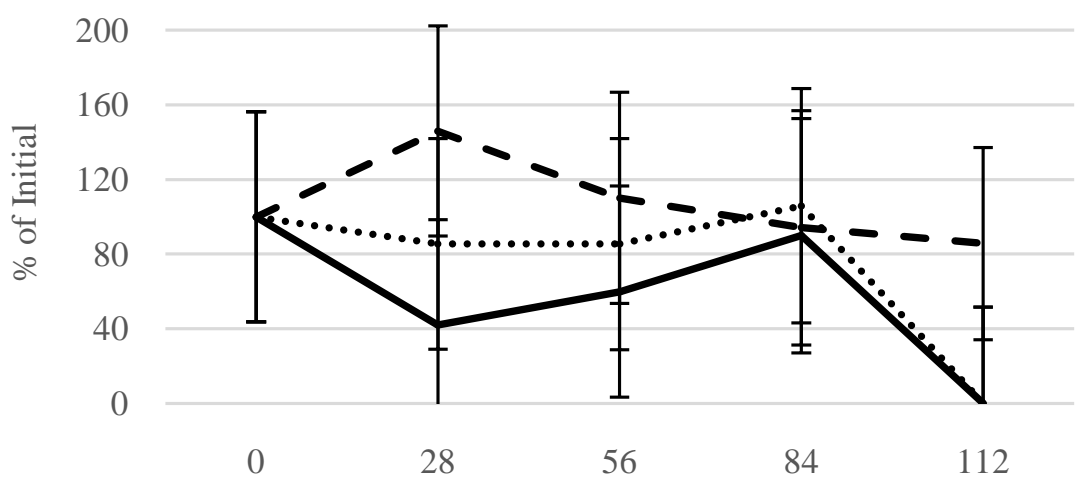

Days After Application

(b)

Figure 5. Water-soluble phosphorus remaining (\% of initial) in fecal pats from cattle grazing pastures receiving $0(0 \mathrm{~N}), 50(50 \mathrm{~N})$, or $100 \%(100 \mathrm{~N}) \mathrm{N}$-fertilization treatments during the cool season (a) and warm season (b). Vertical bars represent standard error of the mean $(n=6)$.

pats; however, the experiment only used a 10-g (DM basis) sample, and disappearance was much less than in the current study for which approximately $74 \%$ disappearance of $\mathrm{P}$ was observed. Another study stated that cow manure due its large proportion of water-soluble $\mathrm{P}$, can be a long-term source of $\mathrm{P}$ that can be transported either by surface water runoff or be leached into the soil [18]. Results of the current study support this concept because almost half of the initial water-soluble $P$ in fecal pats was still remaining in past 112 days later. Additionally, the water-soluble $\mathrm{P}$ in the fecal pats increased from 0 DAA to 28 DAA in the CS. Reference [30] states that manure nutrients have a long-term effect on soil due to their slow mineralization by macro- and microorganisms and chemical reactions within the soil and on the surface. Therefore, the increase in water-soluble P could possibly be due to conversion of organic $\mathrm{P}$ in the manure into water-soluble $\mathrm{P}$.

Percentage of N remaining in fecal pats (Figure 6) was not different $(P>0.10)$ among treatments or between seasons. Zero DAA had a greater $(P<0.001)$ percentage of $\mathrm{N}$ remaining than all other DAAs, and 28 DAA had a greater percentage of $\mathrm{N}$ remaining than 84 and 112 DAA. However, 56, 84 and 112 DAA were not different $(P>0.10)$. Reference [17] observed that $\mathrm{N}$ loss from fecal pats, much like $\mathrm{P}$, mirrored that of fecal pat DM disappearance; this pattern was observed in the current study, with the greatest $\mathrm{N}$ content recorded at 0 DAA and all other subsequent DAA having decreased total $\mathrm{N}$. Additionally, [29] reported that at $87 \mathrm{~d}$ the percentage $\mathrm{N}$ remaining in surface-applied cattle manure was approximately half of the initial.

Extractable soil P concentration data (Table 4) were extremely variable due to uncontrollable environmental factors (air and soil temperature, moisture, etc.) that precluded our ability to discern any statistical differences 


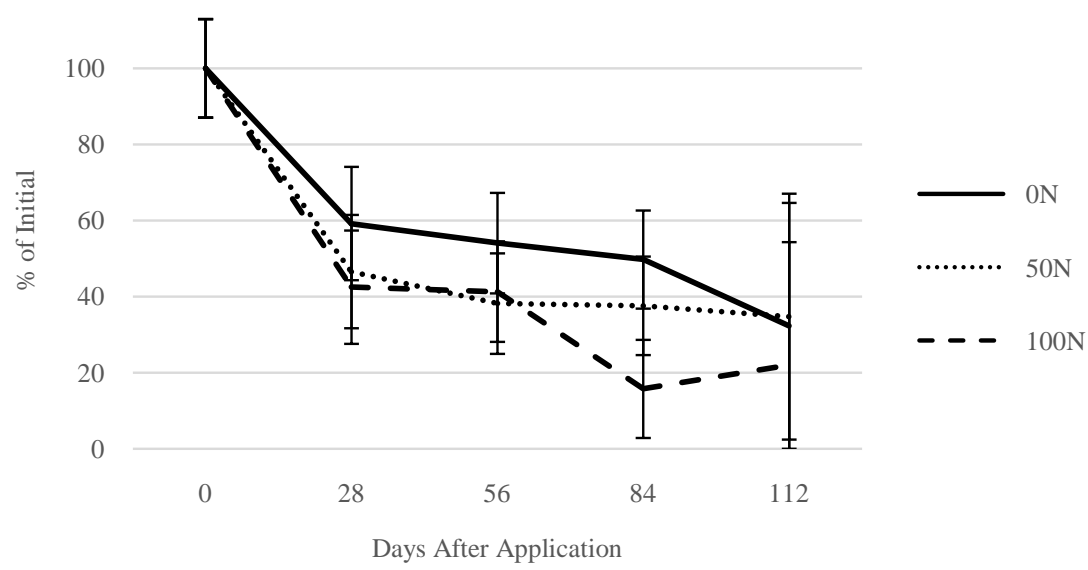

(a)

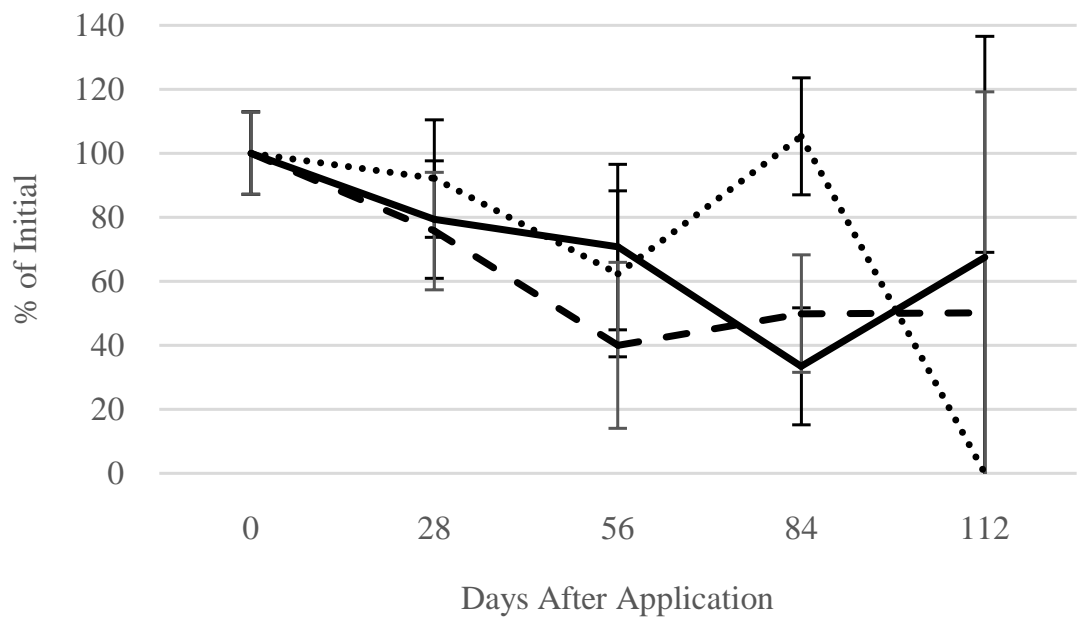

(b)

Figure 6. Total nitrogen remaining (\% of initial) in fecal pats from cattle grazing pastures receiving $0(0 \mathrm{~N}), 50(50 \mathrm{~N})$, or $100 \%(100 \mathrm{~N}) \mathrm{N}$-fertilization treatments during the cool season (a) and warm season (b). Vertical bars represent standard error of the mean $(n=6)$.

among the N-fertilization treatments. However, there was a significant season effect such that soil in the WS contained a greater $\mathrm{P}$ concentration than in the CS. Also, the 0 to $5 \mathrm{~cm}$ depth interval $(115.1 \mathrm{mg} / \mathrm{kg}) \mathrm{had}$ greater $(P<0.001) \mathrm{P}$ concentration than both 5 to 10 and 10 to $20 \mathrm{~cm}(36.4$ and $43.3 \mathrm{mg} / \mathrm{kg}$, respectively); however, 5 to 10 and 10 to $20 \mathrm{~cm}$ were not different $(P>0.10)$. Concentration of soil $P$ on 0 DAA $(31.8 \mathrm{mg} / \mathrm{kg})$ was less $(P<$ $0.060)$ than on both 56 DAA $(67.0 \mathrm{mg} / \mathrm{kg})$ and $112 \mathrm{DAA}(52.9 \mathrm{mg} / \mathrm{kg})$, but was not different from 28 DAA $(98.6 \mathrm{mg} / \mathrm{kg})$ and $84 \mathrm{DAA}(74.6 \mathrm{mg} / \mathrm{kg})$. Also, soil on 28 DAA had greater $(P=0.033)$ soil P concentration than on 56 DAA. Reference [18] reported that P concentration in soil beneath cattle manure had the greatest P concentration from 0 to $2 \mathrm{~cm}(648 \mathrm{mg} / \mathrm{kg})$, and P concentration decreased until 8 to $10 \mathrm{~cm}(236 \mathrm{mg} / \mathrm{kg})$. Reference [31] reported soil-available P varied from year to year; however, soil-available P concentrations at the beginning and end of the study were similar and, therefore, no clear trend of available P accumulation following eight annual applications of dairy cattle manure was observed. This observation is in agreement with our finding in the current study that extractable soil P concentration in the CS returned to approximately initial soil P concentration by 112 DAA and, therefore, annual applications during the CS would likely not result in a buildup of extractable soil P. Warm-season soil P concentrations initially increased 10-fold from DAA 0 to 28, which presumably is a result of the greater rate of disappearance of WS fecal pat P than CS fecal pat P. During the time span of the current study, soil P concentrations did not return to initial P concentrations; however, soil P decreased by at least $150 \mathrm{mg} / \mathrm{kg}$. We propose that the dramatic increase of WS soil P concentrations was possibly 
Table 4. Extractable P concentration $(\mathrm{mg} / \mathrm{kg})$ in soil from beneath feces from cattle grazing pastures receiving different $\mathrm{N}$-fertilization treatments.

\begin{tabular}{|c|c|c|c|c|c|c|c|c|c|c|c|}
\hline \multirow{3}{*}{$\mathrm{DAA}^{\mathrm{b}}$} & \multirow{3}{*}{ Depth, cm } & \multicolumn{5}{|c|}{ Cool Season } & \multicolumn{5}{|c|}{ Warm Season } \\
\hline & & \multicolumn{4}{|c|}{ N Treatment ${ }^{\mathrm{a}}$} & \multirow{2}{*}{$\mathrm{SEM}^{\mathrm{c}}$} & \multicolumn{4}{|c|}{ N Treatment } & \multirow{2}{*}{$\mathrm{SEM}^{\mathrm{C}}$} \\
\hline & & $0 \mathrm{~N}$ & $50 \mathrm{~N}$ & $100 \mathrm{~N}$ & Mean & & $0 \mathrm{~N}$ & $50 \mathrm{~N}$ & $100 \mathrm{~N}$ & Mean & \\
\hline \multirow[t]{3}{*}{0} & 0 to 5 & 31.4 & 42.3 & 41.9 & 38.5 & 47.0 & 30.8 & 34.1 & 32.8 & 32.6 & 35.2 \\
\hline & 5 to 10 & 32.7 & 30.0 & 37.7 & 33.4 & 35.2 & 24.6 & 24.5 & 23.8 & 24.3 & 35.2 \\
\hline & 10 to 20 & 33.7 & 32.9 & 40.6 & 35.7 & 47.0 & 23.3 & 25.5 & 29.4 & 26.1 & 35.2 \\
\hline \multirow[t]{3}{*}{28} & 0 to 5 & 64.6 & 51.0 & 60.2 & 58.6 & 42.3 & 249.3 & 484.5 & 341.2 & 358.3 & 35.2 \\
\hline & 5 to 10 & 38.9 & 27.0 & 37.8 & 34.6 & 35.2 & 59.7 & 78.1 & 55.5 & 47.8 & 35.2 \\
\hline & 10 to 20 & 37.3 & 29.4 & 53.4 & 40.0 & 35.2 & 34.4 & 35.5 & 37.8 & 35.9 & 35.2 \\
\hline \multirow[t]{3}{*}{56} & 0 to 5 & 54.4 & 39.8 & 13.6 & 35.9 & 49.8 & 185.2 & 358.4 & 88.6 & 210.8 & 37.1 \\
\hline & 5 to 10 & 42.7 & 16.5 & 13.8 & 24.3 & 45.5 & 56.3 & 63.5 & 89.1 & 64.4 & 37.1 \\
\hline & 10 to 20 & 33.5 & 30.5 & 21.5 & 28.5 & 49.8 & 32.3 & 48.7 & 17.4 & 32.8 & 40.7 \\
\hline \multirow[t]{3}{*}{84} & 0 to 5 & 20.6 & 40.0 & 74.6 & 45.1 & 35.2 & 205.2 & 244.8 & 183.9 & 211.3 & 37.1 \\
\hline & 5 to 10 & 24.5 & 27.5 & 35.2 & 29.1 & 49.8 & 86.5 & 55.0 & 62.9 & 69.6 & 37.1 \\
\hline & 10 to 20 & 34.5 & 37.2 & 76.6 & 49.4 & 39.0 & 51.2 & 39.9 & 42.2 & 44.4 & 37.1 \\
\hline \multirow[t]{4}{*}{112} & 0 to 5 & 36.5 & 32.4 & 43.3 & 37.4 & 35.2 & 96.8 & 187.5 & 85.5 & 123.3 & 35.2 \\
\hline & 5 to 10 & 28.3 & 20.3 & 63.8 & 37.4 & 43.9 & 37.2 & 66.0 & 40.2 & 68.1 & 35.2 \\
\hline & 10 to 20 & 32.4 & 19.7 & 48.2 & 33.4 & 37.1 & 35.5 & 49.0 & 29.1 & 37.8 & 35.2 \\
\hline & & & \multicolumn{2}{|c|}{ Season Mean } & $37.4^{\mathrm{d}}$ & 11.0 & & \multicolumn{2}{|c|}{ Season Mean } & $92.5^{\mathrm{e}}$ & 9.4 \\
\hline
\end{tabular}

${ }^{\mathrm{a}} 0 \mathrm{~N}=0 \% \mathrm{~N}$ fertilization, $50 \mathrm{~N}=50 \% \mathrm{~N}$ fertilization, $100 \mathrm{~N}=100 \% \mathrm{~N}$ fertilization based on $\mathrm{N}$ requirement of grass species. ${ }^{\mathrm{b}} \mathrm{DAA}=$ days after application. ${ }^{\mathrm{c}} \mathrm{n}=6$. ${ }^{\mathrm{d}, \mathrm{e}}$ Within a row, means without a common superscript differ $(P<0.001)$.

due to above-average rainfall that occurred in both 2010 and 2011 in August and September (DAA 0 - 56), as opposed to the below-average rainfall that occurred during DAA 0 - 56 in the CS. This additional rainfall would maintain optimum soil moisture levels, allowing for maximum $\mathrm{P}$ movement into soil via soil bioactivity.

The total soil $\mathrm{N}$ concentration beneath fecal pats did not vary with time or season. The $0 \mathrm{~N}(1.3 \mathrm{~g} / \mathrm{kg})$ treatment was not different $(P>0.10)$ from [50 N $100 \mathrm{~N}$; ; however, $100 \mathrm{~N}(1.5 \mathrm{~g} / \mathrm{kg})$ had a greater $(P=0.018) \mathrm{N}$ concentration than $50 \mathrm{~N}(1.2 \mathrm{~g} / \mathrm{kg})$. Also, total soil $\mathrm{N}$ decreased $(P<0.061)$ as soil depth increased, with 0 to 5 $\mathrm{cm}$ depth interval $(2.3 \mathrm{~g} / \mathrm{kg})$ having the greatest total soil $\mathrm{N}$ concentration, 5 to $10 \mathrm{~cm}$ having the median value $(1.0 \mathrm{~g} / \mathrm{kg})$, and 10 to $20 \mathrm{~cm}$ having the least value $(0.8 \mathrm{~g} / \mathrm{kg})$. There was a season $\times \mathrm{N}$-fertilization treatment interaction such that $0 \mathrm{~N}(1.2 \mathrm{~g} / \mathrm{kg})$ had less $(P=0.001)$ total $\mathrm{N}$ than $[50 \mathrm{~N}+100 \mathrm{~N}](1.4 \mathrm{~g} / \mathrm{kg})$, and $50 \mathrm{~N}(1.2 \mathrm{~g} / \mathrm{kg})$ had less $(P=0.050)$ total soil $\mathrm{N}$ than $100 \mathrm{~N}(1.7 \mathrm{~g} / \mathrm{kg})$ in the CS. Total soil N concentration decreased with increasing soil depth. Lithourgidis et al. (2007) reported similar findings; i.e., that $\mathrm{N}$ concentration in soils beneath applied cattle manure did not differ between the beginning and end of the experiment (0- to 30-cm soil depth).

\section{Conclusion}

In summary, neither $\mathrm{N}$-fertilization regime nor grazing season affected intake or fecal excretion of water-soluble $\mathrm{P}$ by grazing cattle, but total $\mathrm{P}$ excretion was greater with greater $\mathrm{N}$-fertilization application in the CS. These findings indicated that cattle requirements for $\mathrm{P}$ were met and that sufficient $\mathrm{P}$ was returned to pasture to meet forage requirement for growth in the absence of fertilization with $\mathrm{N}$. There was no effect of $\mathrm{N}$ fertilization on the decomposition of or P removal from fecal pats, or on $\mathrm{P}$ concentration in soil beneath fecal pats. However, $\mathrm{N}$ fertilization increased $\mathrm{N}$ removal from fecal pats and increased total soil $\mathrm{N}$ concentrations beneath fecal pats. These observations are interpreted to mean that, in grazed pastures with high soil-test $\mathrm{P}, \mathrm{N}$ fertilization do not affect intake and fecal returns of $\mathrm{P}$ by grazing cattle, foliar uptake of $\mathrm{P}$, and rate or extent of assimilation of $\mathrm{P}$ returns into the soil profile from degradation of fecal material.

\section{References}

[1] Fame, J. (1971) Fundamentals of Grassland Management. Scottish Agriculture, 50, 28-44.

[2] Saunders, W.M.H. (1984) Mineral Composition of Soil and Pasture from Areas of Grazed Paddocks, Affected and Un- 
affected by Dung and Urine. New Zealand Journal of Agricultural Research, 27, 405-412. http://dx.doi.org/10.1080/00288233.1984.10430642

[3] National Research Coucnil (1996) Nutrient Requirements of Domestic Animals. Beef Cattle. National Academy Press, Washington DC.

[4] Silveria, M.L., Haby, V.A. and Leonard, A.T. (2007) Response of Coastal Bermudagrass Yield and Nutrient Uptake Efficiency to Nitrogen Sources. Agronomy Journal, 99, 707-714. http://dx.doi.org/10.2134/agronj2006.0200

[5] Cherney, D.J.R., Cherney, J.H. and Mikhailova, E.A. (2002) Orchardgrass and Tall Fescue Utilization of Nitrogen from Dairy Manure and Commercial Fertilizer. Agronomy Journal, 94, 405-412. http://dx.doi.org/10.2134/agronj2002.4050

[6] Sistani, K.R., Mays, D.A. and Dawkins, R.A. (2006) Tall Fescue Fertilized with Alum-Treated and Untreated Broiler Litter: Runoff, Soil, and Plant Nutrient Content. Journal of Sustainable Agriculture, 28, 109-119. http://dx.doi.org/10.1300/J064v28n03_09

[7] Sikora, L.J. and Enkiri, N.K. (2005) Comparison of Phosphorus Uptake from Poultry Litter Compost with Triple Superphosphate in Codorus Soil. Agronomy Journal, 97, 668-673. http://dx.doi.org/10.2134/agronj2004.0008

[8] Van Soest, P.J. (1994) Nutritional Ecology of the Ruminant. 2nd Edition, Cornell University Press, New York.

[9] Ternouth, J.H. (1990) Phosphorus and Beef Production in Northern Australia 3. Phosphorus in Cattle-A Review. Tropical Grasslands, 24, 159-169.

[10] Karn, J.F. (1997) Phosphorus Supplementation of Range Cows in the Northern Great Plains. Journal of Range Management, 50, 2-9. http://dx.doi.org/10.2307/4002697

[11] Winter, W.H., Coates, D.B., Hendricksen, R.E., Kerridge, P.C., McLean, R.W. and Miller, C.P. (1990) Phosphorus and Beef Production in Northern Australia 4. The Response of Cattle to Fertilizer and Supplementary Phosphorus. Tropical Grasslands, 24, 170-184.

[12] Winks, L., Lamberth, F.C. and O’Rourke, P.K. (1977) The Effect of a Phosphorus Supplement on the Performance of Steers Grazing Townsville Stylo-Based Pasture in North Queensland. Animal Production Science, 86, 357-366. http://dx.doi.org/10.1071/EA9770357

[13] Barnett, G.M. (1994) Manure P Fractionation. Bioresource Technology, 49, 149-155. http://dx.doi.org/10.1016/0960-8524(94)90078-7

[14] Evers, G.W. (2002) Ryegrass-Bermudagrass Production and Nutrient Uptake When Combining Nitrogen Fertilizer with Broiler Litter. Agronomy Journal, 94, 905-910. http://dx.doi.org/10.2134/agronj2002.9050

[15] Silveria, M.L., Vendramini, J.M.B. and Sollenberger, L.E. (2010) Phosphorus Management and Water Quality Problems in Grazingland Ecosystems. International Journal of Agronomy, 2010, 1-8. http://dx.doi.org/ 10.1155/2010/517 603

[16] Richardson, A.E. (2001) Prospects for Using Soil Microorganisms to Improve the Acquisition of Phosphorus by Plants. Australian Journal of Plant Physiology, 28, 897-906. http://dx.doi.org/10.1071/PP01093

[17] Esse, P.C., Buerker, A., Hiernaux, P. and Assa, A. (2001) Decomposition of and Nutrient Release from Ruminant Manure on Acid Sandy Soils in the Sahelian Zone of Niger, West Africa. Agriculture, Ecosystems, and the Environment, 83, 55-63. http://dx.doi.org/10.1016/S0167-8809(00)00264-4

[18] Chardon, W.J., Aalderink, G.H. and Vand der Salm, C. (2007) Phosphorus Leaching from Cow Manure Patches on Soil Columns. Journal of Environmental Quality, 36, 17-22. http://dx.doi.org/10.2134/jeq2006.0182

[19] Kleinman, P.J., Wolf, A.M., Sharpley, A.N., Beegle, D.B. and Saporito, L.S. (2005) Survey of Water-Extractable Phosphorus in Livestock Manures. Soil Science Society of America Journal, 69, 701-708. http://dx.doi.org/10.2136/sssaj2004.0099

[20] Lupwayi, N.Z. and Haque, I. (1999) Leucaena Hedgerow Intercropping and Cattle Manure Application in the Ethiopian Highlands I. Decomposition and Nutrient Release. Biology and Fertility of Soils, 28, 182-195. http://dx.doi.org/10.1007/s003740050482

[21] Brown, R.Z. (2010) Development of Fertilizer Recommendations for Native Biofuel Crops and Nutrient Release from Cattle Feces. Master's Thesis, Auburn University, Auburn.

[22] Van Soest, P.J., Robertson, J.B. and Lewis, B.A. (1991) Methods for Dietary Fiber, Neutral Detergent Fiber, and Non-Starch Polysaccharides in Relation to Animal Nutrition. Journal of Dairy Science, 74, 3583-3597. http://dx.doi.org/10.3168/jds.S0022-0302(91)78551-2

[23] Tilley, J.M.A. and Terry, R.A. (1963) A Two-Stage Technique for the in Vitro Digestion of Forage Crops. Journal of British Grassland Society, 18, 104-111.http://dx.doi.org/10.1111/j.1365-494.1963.tb00335

[24] Hue, N.V. and Evans, C.E. (1986) Procedures Used for Soil and Plant Analysis by the Auburn University Soil Testing Laboratory. Auburn University, Auburn. 
[25] Streeter, C.L. (1969) A Review of Techniques Used to Estimate the in Vivo Digestibility of Grazed Forage. Journal of Animal Science, 29, 757-768.

[26] Murphy, J. and Riley, J.P. (1962) A Modified Single Solution Method for Determining Phosphate in Natural Waters. Analytica Chimica Acta, 27, 31-36. http://dx.doi.org/10.1016/S0003-2670(00)88444-5

[27] Peterman, R.M. (1990) The Importance of Reporting Statistical Power: The Forest Decline and Acidic Deposition. Ecology, 71, 2024-2027. http://dx.doi.org/10.2307/1937612

[28] Karn, J.F. (2001) Phosphorus Nutrition of Grazing Cattle: A Review. Animal Feed Science Technology, 89, $133-153$. http://dx.doi.org/10.1016/S0377-8401(00)00231-5

[29] Mundus, S., Menezes, R.S.C., Meergaard, A. and Garrido, M.S. (2008) Maize Growth and Soil Nitrogen Availability after Fertilization with Cattle Manure and/or Gliricidia in Semi-Arid NE Brazil. Nutrient Cycling in Agroecosystems, 82, 61-73. http://dx.doi.org/10.1007/s10705-008-9169-z

[30] Eghball, B., Wienhold, B.J., Giley, J.E. and Eigenber, R.A. (2002) Mineralization of Manure Nutrients. Journal of Soil and Water Conservation, 57, 470-473.

[31] Lithourgidis, A.S., Matsi, T., Barbayiannis, N. and Dordas, C.A. (2007) Effect of Liquid Cattle Manure on Corn Yield, Composition, and Soil Properties. Agronomy Journal, 99, 1041-1047. http://dx.doi.org/10.2134/agronj2006.0332 